\title{
Applicability of zymograms for detection of granary weevil (Sitophilus granarius L.) $\alpha$-amylases left on grain after insects infestation
}

\author{
Możliwość zastosowania zymogramów do detekcji $\alpha$-amylaz \\ wołka zbożowego (Sitophilus granarius L.) pozostałych na ziarnie \\ po żerowaniu owadów
}

\author{
Dorota Piasecka-Kwiatkowska ${ }^{1}$, Jan Nawrot ${ }^{2}$, Magdalena Gawlak², Magdalena Zielińska-Dawidziak ${ }^{1}$
}

\begin{abstract}
Summary
50 wheat grains of Korweta variety were infested with ten or twenty males of granary weevil and exposed for five or ten days. After that time the beetles were removed, and the extracts from grains were prepared and zymograms were done. Clearing zones observed on zymograms, showed the presence of granary weevil $\alpha$-amylase in all grain extracts obtained after insects feeding. The obtained revealed that both, hidden grain infestation by the pest, as well as grain contamination with the pest metabolism products were possible to detect using the native electrophoresis with zymograms. Although the intensity of clearing zones was larger when the extracts were obtained from the grain with a greater number of insects feeding for a long time, the relationship between the number of insects, time feeding and $\alpha$-amylase activity was not clearly shown. The amount of granary weevil $\alpha$-amylases left on grain by feeding males was related to the time of feeding as well as individual activity of enzyme secreted by the salivary gland.
\end{abstract}

Key words: granary weevil, grain infestation, $\alpha$-amylase, zymograms

\section{Streszczenie}

Do 50 ziarniaków pszenicy odmiany Korweta wprowadzano po 10 i 20 samców wołka zbożowego i pozostawiono przez okres 5 i 10 dni. Po tym czasie usuwano owady, a z ziarna przygotowywano ekstrakty i sporządzono zymogramy. Na uzyskanych obrazach stwierdzono przejaśnienia świadczące o obecności $\alpha$-amylaz wołka zbożowego we wszystkich ekstraktach ziarna, na którym żerował owad. Uzyskane wyniki wykazały, że elektoroforeza natywna z zymogramami, pozwala na wykrycie ukrytego porażenia ziarna, ale również na wskazanie ziarna, w którym nie ma już owadów, jednak pozostają produkty przemiany materii. Zasadniczo intensywność przejaśnień była większa wówczas, gdy ekstrakty były otrzymywane z ziarna, na którym większa ilość owadów żerowała przez dłuższy czas, jednak nie można jednoznacznie wykazać zależności pomiędzy liczbą owadów, czasem żerowania a aktywnością pozostawionej $\alpha$-amylazy. llość $\alpha$-amylaz pozostawionych na ziarnie przez żerujące samce jest związana zarówno z czasem żerowania owadów, jak i z osobniczą aktywnością enzymu w wydzielinie gruczołów ślinowych.

Słowa kluczowe: wołek zbożowy, porażenie ziarna, $\alpha$-amylazy, zymogramy

\footnotetext{
${ }^{1}$ Uniwersytet Przyrodniczy w Poznaniu

Katedra Biochemii i Analizy Żywności

Mazowiecka 48, 60-623 Poznań

dorotapk@up.poznan.pl

${ }^{2}$ Instytut Ochrony Roślin - Państwowy Instytut Badawczy

Zakład Entomologii

Władysława Węgorka 20, 60-318 Poznań
} 


\section{Wstęp / Introduction}

Wołek zbożowy najchętniej żeruje na ziarnie zbóż, których głównym składnikiem jest skrobia, czym tłumaczy się dużą aktywność enzymów amylolitycznych w przewodzie pokarmowym tego owada. Amylazy są aktywne we wszystkich stadiach rozwojowych wołka, wykazując szczególnie dużą aktywność we wczesnych stadiach larwalnych, gdy następuje znaczny przyrost masy, a w związ$\mathrm{ku} \mathrm{z}$ tym zapotrzebowanie na energię jest znaczne (Rosiński i wsp. 2005). Obserwacje te pozwoliły na opracowanie biochemicznych metod detekcji ukrytego porażenia ziarna, w tym zastosowanie elektroforezy natywnej z zymogramami $\alpha$-amylaz (zgłoszenie patentowe P.392083).

Porażenie ziarna zbóż przez szkodniki związane jest nie tylko $\mathrm{z}$ bezpośrednią obecnością owadów w masie ziarna, ale również z pozostającymi po ich żerowaniu produktami przemiany materii, które mogą mieć właściwości alergenne i także $\mathrm{z}$ tego powodu są niebezpieczne dla konsumentów. W prowadzonych badaniach sprawdzono, czy na podstawie obrazów zymogramów $\alpha$-amylaz wołka zbożowego możliwe jest wykrycie ziarna, w którym nie ma owadów, jaj oraz larw, a pozostały produkty przemiany materii po krótkotrwałym żerowaniu chrząszczy.

\section{Materiały i metody / Materials and methods}

Materiałem do badań było:

1. Ziarno pszenicy ozimej odmiany Korweta, zdrowe oraz porażone wołkiem zbożowym. Próbki porażonego ziarna przygotowano w Zakładzie Entomologii Instytutu Ochrony Roślin - Państwowego Instytutu Badawczego (IOR - PIB) w Poznaniu. Do 50 ziaren wprowadzano po 10 i 20 dorosłych, 1-5-dniowych samców wołka zbożowego. Po 5 i 10 dniach usuwano owady, a ziarno stanowiło materiał do przygotowania ekstraktów amylaz.

2. Larwy i imago wołka zbożowego pochodzące $z$ hodowli własnej IOR - PIB w Poznaniu.

Przygotowanie ekstraktów z ziarna i owadów:

Próbki 50 ziaren pszenicy zdrowej i porażonej oraz 50 sztuk imago i larw wołka zbożowego rozdrabniano w schłodzonym moździerzu, a następnie ekstrahowano amylazy przy użyciu 0,1 M buforu octanowego o pH 5,0.

Detekcja $\alpha$-amylaz wołka zbożowego (zgłoszenie patentowe P.392083):

Obecność $\alpha$-amylaz wołka zbożowego w porażonym ziarnie określano metodą elektroforezy natywnej z wykonaniem zymogramów. Rozdziały elektroforetyczne prowadzono $\mathrm{w}$ jednofazowym 7,5\% żelu poliakrylamidowym z $1 \%$ dodatkiem dekstryny granicznej. Rozdział prowadzono w 0,1 M buforze Tris-glicyna o $\mathrm{pH}$ 9,1 w polu elektrycznym przy stałym napięciu $170 \mathrm{~V}$ z zapewnieniem chłodzenia. Próbki do elektroforezy standaryzowano na podstawie objętości ekstraktu. W celu wywołania zymogramów, żele po rozdziale inkubowano w $0,5 \mathrm{M}$ buforze octanowym o pH 5,0, w temperaturze $25^{\circ} \mathrm{C}$ przez 25 minut, a następnie barwiono w 0,3-procentowym roz- tworze jodu w jodku potasu. Reakcję przerywano po 5 minutach, płucząc żele wodą destylowaną.

Zasadę wykonania zymogramów oparto na zastosowaniu jako substratu dla działania enzymów, dekstryny granicznej, która umożliwia oznaczenie wyłącznie aktywności $\alpha$-amylaz, gdyż $\beta$-amylazy nie są w stanie rozkładać takiej cząsteczki. Zymogramy wywoływano roztworem $\mathrm{I}_{2}$ w KI barwiącym dekstrynę, natomiast niereagującym z produktami jej rozkładu. O aktywności $\alpha$-amylaz świadczyły widoczne na zymogramie przejaśnienia.

\section{Wyniki i dyskusja / Results and discussion}

$\mathrm{Na}$ rysunku 1. przedstawiono zymogramy $\alpha$-amylaz z dekstryną graniczną ekstraktów ziarna pszenicy oraz larw i imago chrząszczy wołka zbożowego. Na zymogramach nie odnotowano aktywności $\alpha$-amylolitycznej w ekstraktach ziarna pszenicy, natomiast stwierdzono dużą aktywność ekstraktów zarówno larw, jak i imago wołka zbożowego. W przewodzie pokarmowym wołka zbożowego dominuje $\alpha$-amylaza, enzym dostosowany do trawienia pokarmów skrobiowych, na których żeruje owad (Baker 1983; Baker 1986; Rosiński i wsp. 2005). W zasiedlanym przez wołka zbożowego ziarnie pszenicy również występują enzymy amylolityczne. Jednak ich aktywność w czasie przechowywania ziarna po zbiorze, gdy może dojść do zasiedlenia przez wołka zbożowego, jest związana głównie $z$ działaniem $\beta$-amylazy, gdyż aktywność $\alpha$-amylazy w dojrzałym ziarnie zanika, wykazując tylko śladową aktywność. Aktywne $\alpha$-amylazy występują w ziarnie tylko w czasie dojrzewania przed zbiorem oraz powtórnie ulegają zaktywowaniu w czasie kiełkowania (Daussant i Corvazier 1970; Ziegler 1999). Pomimo iż, dotychczas donoszono tylko o występowaniu tylko jednego (Baker i Woo 1985; Rosiński i wsp. 2007) w obu ekstraktach uzyskanych z larw i dorosłych chrząszczy wołka zbożowego widocznych jest osiem izoenzymów $\alpha$-amylaz, przy czym jeden wykazuje zdecydowanie największą aktywność. Uzyskane obrazy potwierdziły możliwość detekcji $\alpha$-amylaz wołka zbożowego w ziarnie zbóż na podstawie elektroforezy natywnej.

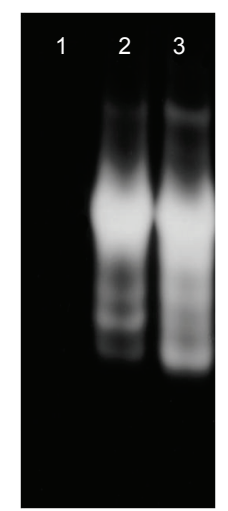

Rys. 1. Zymogramy $\alpha$-amylaz ziarna zbóż (1), larw (2) i imago (3) wołka zbożowego

Fig. 1. Zymograms of wheat (1) and granary weevil larvae (2) and imago (3) $\alpha$-amylases activity 


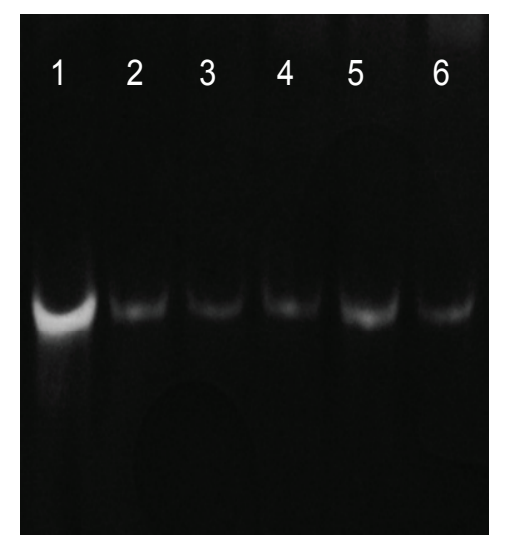

Rys. 2. Zymogramy $\alpha$-amylaz wołka zbożowego uzyskane z ekstraktów ziarna pszenicy, na którym przez pięć $(1,2,3)$ i dziesięć $(4,5,6$,) dni żerowało 10 samców wołka zbożowego

Fig. 2. Zymograms of $\alpha$-amylases activity of extracts of wheat grains infested by 10 male granary weevil during five $(1,2,3)$ an $10(4,5,6)$ days

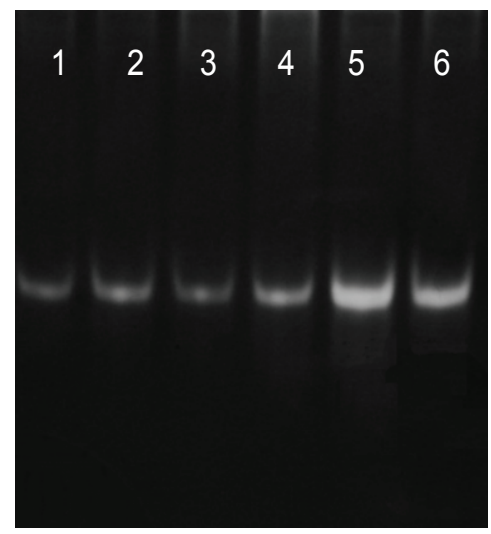

Rys. 3. Zymogramy $\alpha$-amylaz wołka zbożowego uzyskane z ekstraktów ziarna pszenicy, na którym przez pięć $(1,2,3)$ i dziesięć $(4,5,6)$ dni żerowało 20 samców wołka zbożowego

Fig. 3. Zymograms of $\alpha$-amylases activity of extracts of wheat grains infested by 20 male granary weevil during five $(1,2,3)$ and $10(4,5,6)$ days

Na rysunkach 2. i 3. przedstawiono zymogramy $\alpha$-amylaz wołka zbożowego uzyskane $\mathrm{z}$ ekstraktów ziarna pszenicy, na którym przez pięć i dziesięć dni żerowało 10 i 20 samców wołka zbożowego. Na uzyskanych obrazach stwierdzono obecność przejaśnień świadczących o aktywności $\alpha$-amylaz wołka zbożowego we wszystkich ekstraktach ziarna, na którym żerował owad. Zasadniczo intensywność tych przejaśnień była większa wówczas, gdy ekstrakty były otrzymywane z ziarna, na którym większa ilość owadów żerowała przez dłuższy czas (rys. 3). Nie można jednak jednoznacznie wykazać zależności pomiędzy liczbą owadów, czasem żerowania a aktywnością pozostawionej $\alpha$-amylazy. Wynik taki świadczy o tym, że ilość $\alpha$-amylazy pozostawionej na ziarnie przez żerujące samce jest związana $z$ cechami osobniczymi owadów.

Przejaśnienia widoczne na zymogramach $\alpha$-amylaz ekstraktów ziarna, na którym żerowały samce wołka zbożowego pokazują, że zastosowana metoda detekcji pozwala wskazać ziarno, na którym żerował wołek zbożowy, nawet jeżeli owada nie ma już w masie analizowanego ziarna, a także gdy na powierzchni nie są widoczne koreczki świadczące o złożeniu przez samice jaj. Jest to wyjątkowa zaleta tej metody w porównaniu do innych stosowanych do tej pory. Metoda ekspercka przy tak krótkim czasie porażenia pozwala na obserwację pod binokularem i rejestrowanie jedynie koreczków pozostawionych przez samice składające jaja do wnętrza ziarna. Przy pomocy metody rentgenograficznej można już w piątym dniu od złożenia wykryć jaja we wnętrzu ziarniaków lub później larwy (Fornal i wsp. 2007; Nawrocka i wsp. 2012). Metoda rentgenograficzna nie pozwala jednak na wykrycie śladów krótkiego żerowania chrząszczy, gdy owady już nie przebywają na ziarnie, we wnętrzu nie znajdują się jaja czy larwy, ale na powierzchni ziarna pozostawiły jedynie swoje metabolity. Ma to bardzo istotne znaczenie dla poprawy bezpieczeństwa konsumentów. Owady, żerując w masie ziarna, pozostawiają pył, który może być przyczyną alergii pokarmowej czy astmy oskrzelowej piekarzy (Herling i wsp. 1995; Brewczyński 2006). Również same amylazy wołków uznawane są za białka alergenne (Herling i wsp. 1995).

Proponowana metoda detekcji $\alpha$-amylaz wołka zbożowego wydaje się szczególnie atrakcyjnym, nowym narzędziem w zintegrowanym systemie zarządzania kontrolą magazynowanego ziarna, zwiększającym bezpieczeństwo konsumentów, jak również $\mathrm{w}$ postępowaniach reklamacyjnych w obrocie międzymagazynowym.

\section{Wnioski / Conclusions}

1. Elektroforeza natywna $\mathrm{z}$ zymogramami, opracowany wcześniej sposób detekcji ukrytego porażenia ziarna owadzimi szkodnikami, zwłaszcza wołkiem zbożowym, pozwala nie tylko wykryć ukryte porażenie, ale umożliwia także wskazanie ziarna niezasiedlonego, na którym wcześniej żerowały chrząszcze.

2. Ilość $\alpha$-amylazy pozostawionej na ziarnie przez żerujące samce jest związana $\mathrm{z}$ czasem żerowania owadów oraz $\mathrm{z}$ ich cechami osobniczymi związanymi $\mathrm{z}$ aktywnością enzymu w wydzielinie gruczołów ślinowych.

\section{Literatura / References}

Baker J.E. 1983. Properties of amylases from midguts of larvae of Sitophilus zeamais and Sitophilus granarius. Insect Biochem. 13 (4): 421-428. 
Baker J.E. 1986. Amylase/proteinase ratios in larval midguts of ten stored-product insects. Entomol. Exp. Appl. 40: 41-46.

Baker J.E., Woo S.M. 1985. Purification, partial characterization, and postenbryonic levels of amylases from Sitophilus oryzae and Sitophilus granarius. Arch. Insect Biochem. Physiol. 2 (4): 415-428.

Brewczyński P. 2006. Uczulenia na owady. Cz. 1. Alergia 3: 35-42.

Daussant J., Corvazier P. 1970. Biosynthesis and modifications of $\alpha$ - and $\beta$-amylases in germinationg wheat seeds. FEBS Lett. 7 (2): 191-194.

Fornal J., Jeliński T., Sadowska J., Grundas S., Nawrot J., Niewiada A., Warchalewski J.R., Błaszczak W. 2007. Detection of granary weevil Sitophilus granarius (L.) eggs and internal stages in wheat grain using soft X-ray and image analysis. J. Stored Prod. Res. 43 (2): 142-148.

Herling C., Svendsen U.G., Schou C. 1995. Identification of import ant allergenic proteins in extract of the granary weevil (Sitophilus granarius L.). Allergy 50 (5): 441-446.

Nawrocka A., Stępień E., Grundas S., Nawrot J. 2012. Mass loss determination of wheat kernels infested by granary weevil from X-ray images. J. Stored Prod. Res. 48 (1): 19-24.

Nawrot J., Gawlak M. 2009. Zanieczyszczenia biologiczne jako problem bezpieczeństwa żywności. Prog. Plant Prot./Post. Ochr. Roślin 49 (1): 445-450.

Rosiński M., Piasecka-Kwiatkowska D., Warchalewski J.R. 2005. Aktywność amylolityczna wołka zbożowego w różnych stadiach rozwojowych. Prog. Plant. Prot./Post. Ochr. Roślin 45 (1): 418-422.

Rosiński M., Piasecka-Kwiatkowska D., Warchalewski J.R. 2007. Określenie liczby izoenzymów $\alpha$-amylazy wołka zbożowego w różnych stadiach rozwojowych. Prog. Plant Prot./Post. Ochr. Roślin 47 (1): 359-362.

Ziegler P. 1999. Cereal beta-amylases. J. Cereal Sci. 29 (3): 195-204. 